\title{
PREDICTION SUSTAINABILITY COMPANY USING ARTIFICIAL NEURAL NETWORK
}

\author{
Rizka Noor Rifa ${ }^{1}$ \\ Muhamad Muslih ${ }^{2}$ \\ Telkom University Bandung \\ rizkanoorrifa@gmail.com
}

\author{
A R T I C L E I N F O \\ Article history: \\ Received :10 Juli 2018 \\ Revised : 23 September 2018 \\ Accepted : 29October 2018 \\ JEL Classification: \\ Key words: \\ Sustainability, GRI-G4, ASRR, \\ Artificial Neural Network
}

DOI: https://doi.org/10.33508/rima.v1i2.2674

\begin{abstract}
A B S T R A C T
The study aims to find out how to predict company sustainability using Artificial Neural Networks (ANN) and looks at the relationship of board tenure, board age, company size, profitability, leverage, and liquidity in predicting sustainability of Asia Sustainability Reporting Rating (ASRR) participants in Indonesia period 2009-2018. Previous studies state that ANN is considered to provide accurate results in predictions. Therefore, this study uses ANN modeling for predicting sustainability. Company sustainability is assessed by analyzing sustainability performance in the Company's Sustainability Report based on the Global Reporting Initiatives (GRI) G4 guidelines. The results of predictions using ANN indicate that company size, liquidity, and leverage contribute more than $50 \%$ in predicting company sustainability. Meanwhile, profitability, board age, and biard tenure contribute less than $50 \%$.
\end{abstract}

\section{INTRODUCTION}

Genetic damage caused by Company activities can be detrimental to the community, the government, and the company itself. Therefore, consideration of business sustainability is as important as profit for the company. This is an encouragement for companies to carry out Corporate Social Responsibility (CSR) activities. The company's obligation in presenting CSR activities in annual reports or separate reports such as sustainability reports is contained in the Decree of the Chairperson of the Capital Market and Financial Institution Supervisory Agency Number KEP-431 / BL / 2012. The stakeholder theory approach is one of the reasons for companies to express CSR better.
Both the annual report and the sustainability report become a tangible form that a company has done transparency on the risks and opportunities faced. This everincreasing transparency can influence stakeholder decision making, so it becomes an excellent opportunity for companies to maintain and enhance reputation. This transparency shows that the company has tried to reveal all the information needed by stakeholders. Disclosures made in the sustainability report can be used to assess the company's sustainability performance. Thus, the more exposure, the company's sustainability performance is considered better (Anggraeni, 2018).

The information booth in the sustainability report and the annual report is one factor for stakeholders in making 
decisions. This is because they do not want to blame for its negligence in treating the existing environment, society, and economy. But in reality, although the company won the ASRR in 2009-2018, CSR disclosure in the ASRR participating companies in Indonesia in 2009-2018 fluctuated, means the company's concern for stakeholders still varies. The company's exposures to meet the needs of these stakeholders can be a consideration to find out how the company's sustainability was going forward.

Information about the company not only from the sustainability report but also from the annual report means a statement that must be made by the company based on the Financial Services Authority (OJK) regulation no. 29 / POJK.04 / 2016. The annual report issued by this company can illustrate the board's diversity and the characteristics of the company. The board's diversity described with several variables: board tenure and board age. Also, company characteristics can be characterized by several variables, such as company size, profitability, leverage, and liquidity. Therefore, the input variables used to predict company sustainability in this study are board tenure, board age, company size, profitability, leverage, and liquidity. The six variables found related to the quality of CSR disclosure are the basis of the company's sustainability assessment.

Research conducted by Albahussain, El-Garaihy, and Mobarak (2014) has proven that ANN can be a significant method for understanding corporate CSR evaluations and providing an approach that encourages data processing in CSR. The research focused on the triple bottom line in CSR alone. Thus, researchers are interested in predicting a company's sustainability using ANN by using six input variables, namely board tenure, board age, company size, profitability, leverage, and liquidity.

\section{LITERATURE REVIEW}

Artificial Neural Networks

According to Hermawan (2006: 37) stated, ANN is a computational system where architecture and operations are inspired by the knowledge of biological nerve cells in the brain, which is one of the false representations of the human brain that always tries to stimulate the learning process in the human brain. While Suyanto (2008: 58) provides a more straightforward understanding of ANN as a network architecture to model human nerves in carrying out specific tasks.

According to Floreano and Mattiussi (2008: 189), ANN architecture affects the functionality and types of learning algorithms used. They divided the ANN architecture into several kinds: Single-Layer Feedforward Network (SLFN), Multi-Layer Feedforward Network (MLFN), Recurrent Connection Auto-Associative Networks and Echo State Networks. ANN architecture used in this study is MLFN because some studies have mentioned that MLFN can solve problems that are more difficult than SLFN, so it is often used to predict a value. As the name implies, MLFN is an ANN architecture which has one or more hidden layers (Puspitaningrum, 2006: 12). In addition to the input and output layers like the SLFN has, there are hidden layers located between them. This layer is what distinguishes MLFN from SLFN. MLFN also has layers of weights between the two layers.

Weights in ANN are determined by selecting learning processes (learning process) that are used following the architecture of ANN that is built. According to Floreano and Mattiussi (2008: 196), there are two main types of learning processes, namely unsupervised learning and supervised learning. This research will use supervised learning, where there will be a training process (training) and a testing process (testing). The training process is a teacher to get the expected results from the network in each pattern. With this modified weight assessment, it is expected to reduce errors between the desired answers and the answers given by the system (Floreano \&Mattiussi, 2008: 219).

As explained previously in BPNN, there will be a training process to study the patterns to obtain the expected results. This process will be carried out many times and 
continue to be modified to produce a network that provides answers on target. The solution that fits this target is the answer between the difference between the response generated by the system with the specified goal or an acceptable error. Measurement of mistakes can be done using the Sum of Squares Error (SSE) or average error rate (MSE - Mean Square Error) (Suyanto, 2008: 83).

\section{Theory stakeholder}

In this study, the underlying theory used in stakeholder theory. This study will also discuss the dependent, sustainability, and independent variables, board tenure, board age, leverage, profitability, company size, and liquidity. These used by research and other material expected to help research, such as understanding management strategic, ethical and corporate governance, and Corporate Social Responsibility (corporate social responsibility).

Freeman (2010: 26) defines stakeholders as a group or individual who can influence or be influenced by realizing organizational goals. The stakeholder approach to business is about making as much value as possible for stakeholders. A possible way to maximize profit on an ongoing basis is by satisfying stakeholder interests.

This theory shows that the board of directors, which is the company's primary control mechanism, is responsible both in making decisions and in completing its duties to stakeholders (Rao \& Tilt, 2016). In managing the company's relationship with stakeholders, the company must conduct proper management (Setiawan, Hapsari, \&Wibawa, 2018). Setiawan, Hapsari, and Wibawa (2018) mentioned that managers have a unique position in providing benefits to all stakeholders. If interdependence is formed between the two, a match of interests will also be created (Setiawan et al., 2018).

Reputation is an ongoing competitive advantage because it has the following four attributes valuable, difficult to imitate, irreplaceable, and rarely possessed by other competitors (Barney, 1991). This reputation is an attraction for stakeholders because it is an added value for the company. Status can be influenced by company CSR. The more CSR disclosed, the stakeholders would get the more information they need. So, this can be interpreted that the company has tried to satisfy the interests of stakeholders.

\section{Strategy Management and its relation to CSR}

David and David (2017: 42) explain that several things affect overall strategic management, including ethics, social responsibility, and sustainability. Principles in organizations that guide decision making and behavior are referred to as business ethics (David \& David, 2017: 96). With good ethics, the management strategy can work well. So it can be concluded that good ethics is good business.

CSR is a form of ethical application. By carrying out CSR activities, the company has a broader business role than just making a profit. The necessary foundation of CSR is the Triple Bottom Line (TBL) concept. TBL explains the three different focuses that must be prepared by the company, namely: environment (planet), social (people), and economy (profit). The three concentrations in TBL explain the purpose of sustainability. David and David (2017: 96) mention that sustainability refers to the extent to which organizations' actions and operations preserve, improve, and protect rather than damage the natural environment.

\section{Continuity}

Sustainability assessments are described by Kassem et al. (2017) as business activities in general that demonstrate the relationship between organizational strategy and commitment to a sustainable global economy. The basic framework commonly used in sustainability reporting is the Global Reporting Initiative (GRI) standards. In assessing sustainability performance, this standard is widely used. This research uses GRI-G4 as a guideline for the GRI standard. GRI-G4 has 91 aspects, which are divided into 
three categories, namely social, environmental, and economical.

Board Characteristics and Corporate Sustainability

In a study conducted by Handajani et al. (2014), the board members referred to in companies in Indonesia were members of the board of commissioners. In a study conducted by Handajani et al. (2014), the board members referred to in companies in Indonesia were members of the board of commissioners. Members of the board of commissioners have supervisory duties. They are responsible for overseeing management policies, the company's course in general, both regarding the company and the company's business and advising directors (Financial Services Authority, 2014: 15). Also, the board of commissioners can dismiss members of the board of directors temporarily and can take management actions of the company (Financial Services Authority, 2014: 16). The board of commissioners also has the task of reviewing the company's annual report made by the board of directors (Financial Services Authority, 2016: 3).

CSR activities can be disclosed in annual reports or separate reports, such as sustainability reports. It has been explained that the disclosure of CSR activities is done to meet stakeholders' needs. Everyone has different opinions so that various councils will also produce different decisions in carrying out their duties. The board's diversity in this study was seen from the tenure (board tenure) and his age (board age).

The diversity of the board can not only be described by board tenure. Another indicator that can illustrate the variety of the board is board age. Board age can be measured by the average age of board members (Giannarakis, 2014). Post et al. (2011) state that based on empirical evidence in previous studies, both young and old, are now more environmentally oriented. The age of a council can describe the board's professional experience (Adib and Xianzhi, 2019). Thus, younger councilors are no more experienced than older ones. However, they prefer to take risks because they can use new administrative tools to be more oriented towards new management strategies (Giannarakis, 2014). One example of this management strategy is CSR. Thus, when board age is high, CSR disclosure is low. This can show that there is a relationship between board age and CSR disclosure.

H1: There is a relationship between board tenure and company sustainability.

$\mathrm{H} 2$ : There is a relationship between board age and company sustainability.

Company Characteristics and Company
$\frac{\text { Sustainability }}{\text { Company characteristics can be }}$
described by company size, profitability, leverage, and liquidity (Gunardi, Febrian, \&Herwany, 2016; Habbash, 2016; Nasir, Ilham, \& Utara, 2014; Zainal, 2017). Company size is one indicator that can describe the characteristics of the company. Bruke et al. (in Adib and Xianzhi, 2019) stated that there would be many stakeholders interested in the growing company. Also, larger companies tend to have more resources to carry out CSR (Harjoto and Rossi, 2019). This can show that there is a relationship between company size and CSR disclosure.

Profitability shows the company's ability to generate profits. Increased profits will increase disclosures presented by management. This is done so that the company can attract stakeholder interest (Zainal, 2017). As explained earlier, the purpose of CSR disclosure is to meet stakeholder needs. Both of these company activities illustrate that stakeholders are targeted for what the company is doing to continue going forward. Therefore, this study looks at the relationship between profitability and CSR disclosure.

Leverage is a measurement of the extent to which a company can fund its longterm debt (Subramanyam\& Wild, 2010: 38). The company certainly wants to be financed 
by its stakeholders, so the company will reflect its good condition by reporting higher profits. The company can reduce the actual costs to produce this higher profit. One form of expenses incurred by companies is the cost of disclosing sustainability reports. Thus, companies tend to reduce this report's level of disclosure (Nasir et al., 2014). This can show that there is a relationship between leverage and CSR disclosure.

Liquidity can be used to measure the extent to which a company can fund its shortterm debt (Subramanyam\& Wild, 2010: 528). The company's performance will be considered good if the company has the right level of liquidity. So that liquid companies will tend to disclose CSR better (Gunardi et al., 2016).Thus, the company will make proper disclosures about the company, including disclosing its CSR activities to maintain its reputation. A liquid company will tend to disclose CSR better, which means there is a relationship between liquidity and CSR disclosure.
H3: There is a relationship between company size and company sustainability.

H4: There is a relationship between profitability and corporate sustainability.

H5: There is a relationship between leverage and corporate sustainability.

H6: There is a relationship between liquidity and company sustainability.

\section{Analysis Model}

This study uses ANN to determine the relationship between board tenure, board age, company size, profitability, leverage, and liquidity in predicting the company's sustainability. This study also sought the best ANN model to predict company sustainability. ANN architecture in this study uses three layers: the input layer in which there are six input variables, the hidden layer in which there are several hidden units, and the output layer consisting of 1 group of the output variable. Based on the ANN architecture, the framework of thought in the study is illustrated in Figure 1.

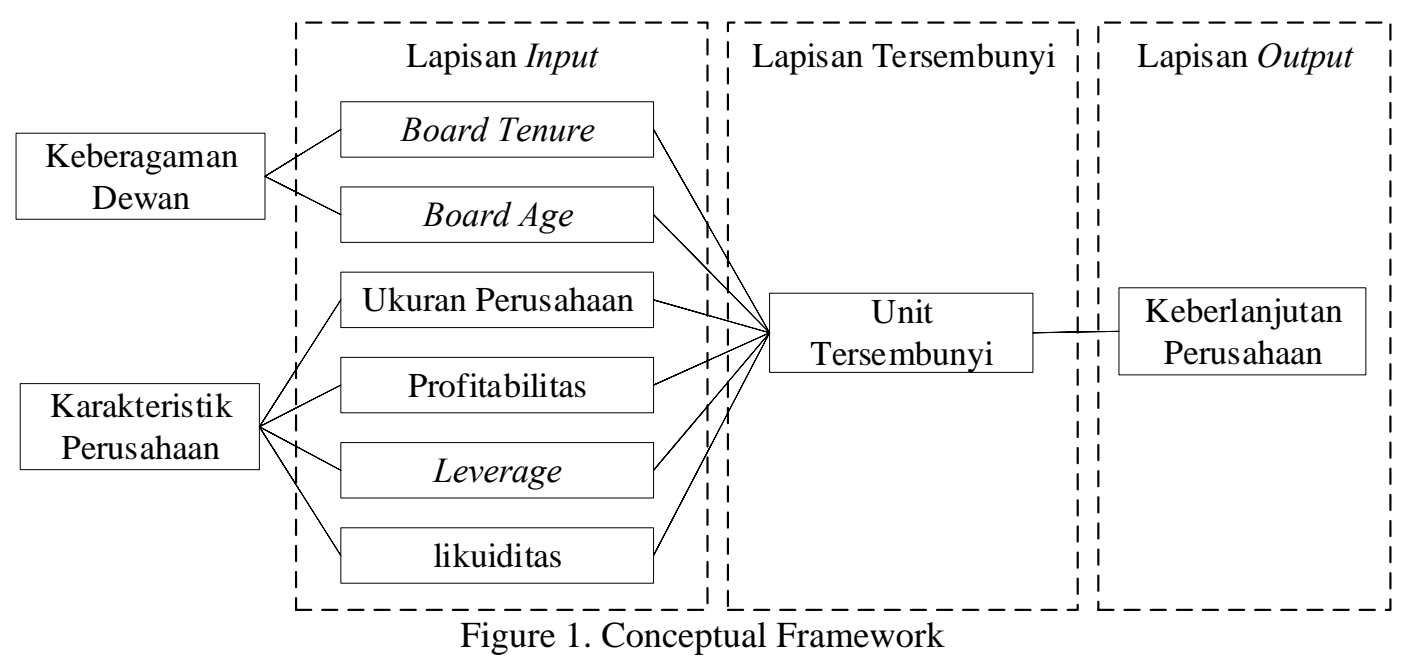

\section{METHODOLOGY}

Population and Research Samples

This study takes a case in the company participating in the Asia Sustainability Reporting Rating (ASRR) in Indonesia in 2009-2018. Only companies have won awards for five years in a row and have reported the Annual Report and the Sustainability Report consistently separately in 2009-2018. Therefore, this research uses purposive sampling as a sampling technique. The time needed to implement changes that might occur must be included in the forecast horizon (Stevenson, 2012: 76). Therefore, a long period becomes the sampling criterion because the data used is annual data. Three companies meet the sample criteria in this 
study: PT Aneka Tambang, PT Bank Negara Indonesia, and PT Perusahaan Gas Negara.

\section{Method of collecting data}

Documentation and literature review are used as data collection techniques. A literature study is an activity to explore, identify, examine, and examine knowledge from various sources such as journals, books, etc. (Fitriah, 2017: 138). Meanwhile, records of past events that can be in pictures, writings, or monumental works from someone are called documentation (Sugiyono, 2015: 329).

\section{Research variable}

The company's sustainability, which is the output variable in this study, evaluates the company from its sustainability performance. This performance evaluation is based on the number of CSR disclosures in the Sustainability Report using GRI-G4 guidelines. This study's input variables are board tenure, board age, company size, profitability, leverage, and liquidity with the measurement tools described in Table 1.

Table 1. Summary of Measurement of Research Variables

\begin{tabular}{|c|c|c|}
\hline Variable & Akronim & Measurement \\
\hline Sustainability & SUS & $\begin{array}{c}\text { CSR index which devides the actual value of CSR } \\
\text { disclosed by the company with the maximum amount } \\
\text { of CSR that the company should disclose }\end{array}$ \\
\hline Board Tenure & BTEN & The average length of board members \\
\hline Board Age & BAGE & The average age of board members \\
\hline Size & SIZE & Natural logarithm of total assets \\
\hline Profitability & PRO & ROA (Percentage of net income to total assets) \\
\hline Leverage & LEV & DER (Percentage of total debt to total equity) \\
\hline Liquidity & LIK & $\begin{array}{c}\text { Current Rasio(Percentage of current asset to current } \\
\text { liability) }\end{array}$ \\
\hline
\end{tabular}

\section{Data analysis technique}

This study uses IBM SPSS Statistics 23 as a device used in the data processing. In addition to testing the ANN model, this study also calculated the Determination Coefficient (R2) and the Correlation Coefficient Test. According to Widarjono (2013, 179), the coefficient of determination (R2) essentially measures how far the model can explain variations in the dependent variable. The value of R2 lies between 0 and 1 . A model is useful if the value of $R 2$ is close to 1 and vice versa if $R 2$ is close to 0 , then the model is not good. The small amount of R2 shows the independent variable's ability to explain the variation of the dependent variable is minimal. But the dependent variable is replaced by the output variable, and the input variable overrides the independent variable.
Taghizadeh and Kermani (2011) state that the correlation cofisin between the predicted data and the target data is used to assess the two's compatibility trend. Sarwono and Halim (2017: 67-68) state that one of the two popular techniques for measuring correlation is the Pearson product-moment correlation used on interval or ratio scale data. The variables in this study use ratio scale data. Therefore, this study uses the Pearson product-moment correlation.

\section{Coefficient of Detemination $\left(R^{2}\right)$}

The coefficient of determination $\left(\mathrm{R}^{2}\right)$ can measure the extent of the model's ability to explain output variables' variations. $\mathrm{R}^{2}$ value, which is getting closer to 1 , shows a good model, and vice versa. Table 2 shows that $\mathrm{R}^{2}$ is worth $51.1 \%$. This interpreted that $51.1 \%$ of the company's sustainability values' 
diversity can be explained by board tenure, board age, size, profitability, leverage, and liquidity. In comparison, $48.9 \%$ is explained by other variables outside the model.

Table 2. Coefficient Determination

\begin{tabular}{|l|l|l|l|l|l|}
\hline Model & $\mathrm{R}$ & $\begin{array}{l}\mathrm{R} \\
\text { Square }\end{array}$ & $\begin{array}{l}\text { Adjusted } \mathrm{R} \\
\text { Square }\end{array}$ & $\begin{array}{l}\text { Std. Error of the } \\
\text { Estimate }\end{array}$ & $\begin{array}{l}\text { Durbin- } \\
\text { Watson }\end{array}$ \\
\hline 1 &, $715^{\mathrm{a}}$ & 0,511 & 0,383 & 0,21791 & 1,94 \\
\hline
\end{tabular}

\section{Correlation Coefficient Test}

The correlation coefficient test results in this study can be seen in Table 3. Pearson product-moment correlation coefficient test results showed a value of 0.842 . Based on
Table 4, 0.842 is between 0.075 and 0.99 , which means that the match between the predicted results and the predicted targets is considered very strong.

Table 3. Correlation

\begin{tabular}{|ll|r|r|}
\hline & Keberlanjutan & Predicted Value for Y_Sus \\
\hline Keberlanjutan & 1 &, $842^{* *}$ \\
& Pearson Correlation & &, 000 \\
Sig. (2-tailed) & 30 & 30 \\
$\mathrm{~N}$ &, $842^{* *}$ & 1 \\
\hline Predicted Value for Y_Sus Pearson Correlation &, 000 & 30 \\
& Sig. (2-tailed) & 30 & 30 \\
$\mathrm{~N}$ & &
\end{tabular}

**. Correlation is significant at the 0.01 level (2-tailed).

\section{IST Model Analysis}

This study tried 150 different parameters (3 different hidden units, ten different learning rates, and five different momenta). The 150 experiment results can be seen in Appendix 10 get 1 model that shows the one best parameter with the lowest Sum of
Squares Error (SSE). The settings that produce the best JST model are the parameters with three hidden units in 1 hidden layer, a momentum of 0.7 , and a learning rate of 0.5 .

Table 4. JST Model

\begin{tabular}{|ll|l|}
\hline Training & Sum of Squares Error & 0,405 \\
& Relative Error & 0,309 \\
& Stopping Rule Used & $\begin{array}{l}\text { Relative change in training error } \\
\text { criterion }(, 0001) \text { achieved } \\
0: 00: 00,02\end{array}$ \\
& Training Time & 0,059 \\
Testing & Sum of Squares Error & 0,216 \\
& Relative Error & \\
\hline
\end{tabular}

Table 4 shows the SSE produced from the best parameters is 0.405 in the training data and 0.059 in the test data. Learning is stopped when the relative changes in error training have been achieved after going through 0.02 seconds of exercise. This ANN 
model can provide results in the form of how much the contribution of independent variables in predicting the dependent variable. The gift of each independent variable can be seen in Table 3.

Table 5. Independent Variable

\begin{tabular}{|c|c|c|}
\hline Variabel & Importance & Normalized Importance \\
\hline SIZE &, 295 & $100,0 \%$ \\
\hline LIK &, 279 & $94,7 \%$ \\
\hline LEV &, 191 & $64,9 \%$ \\
\hline PRO &, 109 & $37,0 \%$ \\
\hline BAGE &, 105 & $35,6 \%$ \\
\hline BTEN &, 021 & $7,2 \%$ \\
\hline
\end{tabular}

Table 5 shows that company size, liquidity, and leverage have high contributions with normalized importance values above $50 \%$. While profitability, board age, and board tenure have a low gift with normalized importance below 50\%. The weight of this contribution shows how vital the input variables are in predicting sustainability performance. It can also illustrate how the relationship between input variables and output variables. Thus, Table 5 also shows that there is a relationship between the input variables and company sustainability. If the input variables are sorted from those with the highest contribution weight, the composition is company size (0.295), liquidity (0.279), leverage (0.191), profitability (0.109), board age (0.105), and board tenure (0.021).

\section{Discussion}

Relationship between Board Tenure and $\underline{\text { Sustainability }}$

As explained in the previous chapter, board members who are too long in office will be more experienced than those who have just served (Handajani et al., 2014). However, they will be closer to management to influence the decision-making process and weaken supervision, control, and monitoring among board members (Rao \& Tilt, 2016). So that when board tenure is high, CSR disclosure is low. This can show that there is a relationship between board tenure and CSR disclosure. However, this study found that the contribution weight of board tenure in predicting company sustainability was only 0.021 , and this was the lowest weight compared to the five other input variables. This can mean that compared to other input variables, the board tenure relationship in predicting its sustainability is minimal.

Relationship between Board Age and Sustainability

The diversity of the board can not only be described by board tenure. Another indicator that can illustrate the variety of the board is board age. Board age can be measured by the average age of board members (Giannarakis, 2014). Post et al. (2011) state that based on empirical evidence in previous studies, both young and old, are now more environmentally oriented. The council's age can describe the professional experience of the board (Adib and Xianzhi, 2019). Thus, younger councilors no more experienced than older ones. However, they prefer to take risks because they can use new administrative tools to be more oriented towards new management strategies (Giannarakis, 2014). One example of this management strategy is CSR. Thus, when board age is high, CSR disclosure is low. This can show that there is a relationship between board age and CSR disclosure. However, this study found that the weight of the contribution of board age in predicting the sustainability of the company amounted to 0.105 , and this is the second-lowest weight of the six input variables. This can mean that compared to other input variables, the board 
tenure relationship in predicting its sustainability is still relatively small.

Relationship between Company Size and Sustainability

Company characteristics can be described by company size, profitability, leverage, and liquidity (Gunardi et al., 2016; Habbash, 2016; Nasir et al., 2014; Zainal, 2017). Company size is one indicator that can describe the characteristics of the company. Proxies that can be used in assessing company size are natural logarithms of total assets (Nasir, Ilham, and Utara, 2014). Bruke et al. (in Adib and Xianzhi, 2019) stated that there would be many stakeholders interested in the growing company. Also, larger companies tend to have more resources to carry out CSR (Harjoto and Rossi, 2019). This can show that there is a relationship between company size and CSR disclosure.

This study found that the weight of the contribution of company size in predicting corporate sustainability amounted to 0.295 , and this is the highest weight compared to the five other input variables. This can mean that compared to other input variables, the relationship between company size in predicting company sustainability is very high.

Relationship between Profitability and Sustainability

Profitability shows the company's ability to generate profits. The proxy that is commonly used in profitability is the return on assets (ROA) (Zainal, 2017). The higher the benefits, the greater the disclosures presented by management. This is done so that the company can attract stakeholder interest. As explained earlier, the purpose of CSR disclosure is to meet stakeholder needs. Both of these company activities illustrate that stakeholders are targeted for what the company is doing to continue going forward. Therefore, this study looks at the relationship between profitability and CSR disclosure.

This study found that the weight of the contribution of profitability in predicting the sustainability of the company amounted to 0.109 , and this is the third lowest weight of the six input variables. This can mean that compared to other input variables, the relationship of profitability in predicting the company's sustainability is still higher than the two variables that describe the diversity of the board but is the lowest compared to the variables that describe the characteristics of the company.

\section{Relationship between Leverage and Sustainability}

Leverage is a measure of the extent to which a company can fund its long-term debt. The leverage measurement proxy in this study uses debt to equity ratio (DER) (Giannarakis, 2014). The company certainly wants to be funded by its stakeholders, so the company will reflect its good condition by reporting higher profits. One way that can be done to produce high profits is to reduce existing costs. Disclosure of sustainability reports separately requires time and costs, so companies will tend to minimize this report's level of exposure. This can show that there is a relationship between leverage and CSR disclosure.

The results of this study found that the weight of the contribution of leverage in predicting the sustainability of the company amounted to 0.91 , and this is the third-highest weight of the six input variables. This can mean that compared to other input variables, the relationship of leverage in predicting the company's sustainability is quite high but still not higher than the company's liquidity and size.

Relationship between Liquidity and Sustainability

Liquidity can be used to measure the extent to which a company can fund its shortterm debt. The proxy commonly used is the current ratio (Gunardi et al., 2016). The company will be considered good if the company has the right level of liquidity. This becomes the company's added value in the eyes of stakeholders. Thus, the company will make proper disclosures about the company, including disclosing its CSR activities to 
maintain its reputation. A liquid company will tend to disclose CSR better, which means there is a relationship between liquidity and CSR disclosure.

This study found that the weight of the contribution of liquidity in predicting the sustainability of the company amounted to 0.279 , and this is the second-highest weight of the six input variables. This can mean that compared to other input variables, the liquidity relationship in predicting the company's sustainability is quite high but still not higher than the size of the company.

\section{CONCLUSION}

The determination test coefficient shows that $51.1 \%$ of the diversity of sustainability values explained by board tenure, board age, company size, profitability, leverage, and liquidity. In comparison, $48.9 \%$ explained by other variables outside the model. The correlation coefficient test results in this study showed that the match between the predicted results and the predicted targets was considered very strong. ANN model shows that company size, liquidity, and leverage have a high contribution with normalized importance value above $50 \%$. While profitability, board age, and board tenure have a low gift with normalized importance below $50 \%$. If the input variables were sorted from those with the highest contribution weight, the composition is company size (0.295), liquidity (0.279), leverage (0.191), profitability (0.109), board age (0.105), and board tenure (0.021). The weight of this contribution can show how the relationship between the input variables in predicting sustainability performance. It can be seen that company size has the highest participation level, while board tenure is in the lowest position. So it can be concluded that company size has a long relationship to company sustainability.

\section{REFERENCES}

Adib, M., \& Xianzhi, Z. (2019). Board Characteristics and Corporate Social Performance Nexus- A Multi-theoretical
Analysis - Evidence from South Africa. IOSR Journal of Business and Management, 21(1), 24-38. https://doi.org/10.9790/487X2101042438

Albahussain, S. A., El-Garaihy, W. H., \& Mobarak, A. M. (2014). The Prediction of Corporate Social Responsibility Impact on Competitive Advantage: An Artificial Neural Network Approach. International Journal of Academic Research in Economics and Management Sciences, 3(5), 129-150. https:/ / doi.org/10.6007/IJAREMS/v3i5/1197

Anggraeni, D. Y. (2018). Pengujian Terhadap Kualitas Pengungkapan CSR di Indonesia. Ekuitas: Jurnal Ekonomi Dan Keuangn, 2(1), 22-41. https://doi.org/10.24034/j25485024.y20 18.v2.i1.2457

Barney, J. (1991). Firm Resources and Sustained Competitive Advantage. Journal of Management, 17(1), 99-120. https://doi.org/10.1177/0149206391017 00108

David, F. R., \& David, F. R. (2017). Strategic Management: A Competitive Advantage Approach, Concepts and Cases (16th ed.). Harlow: Pearson Education.

Fitriah, M., \& Luthfiyah. (2017). Metodologi Penelitian: Penelitian Kualitatif, Tindakan Kelas dan Studi Kasus. Sukabumi: Jejak.

Floreano, D., \& Mattiussi, C. (2008). Bio Inspired Artificial Intelligence Theories, Methods, And Technologies. Retrieved from

https://archive.org/details/2008BioInsp iredArtificialIntelligenceTheoriesMethod sAndTechnologiesDarioFloreano/page/ n243

Freeman, R. E., Harrison, J. S., Wicks, A. C., Parmar, B., \& Colle, S. de. (2010). 
Stakeholder Theory: The State of the Art. New York: Cambridge University.

Giannarakis, G. (2014). Corporate governance and financial characteristic effects on the extent of corporate social responsibility disclosure. Social Responsibility Journal, 10(4), 596-590. https:/ / doi.org/10.1108/SRJ-02-20130008

Gunardi, A., Febrian, E., \& Herwany, A. (2016). The implication of firm-specific characteristics on disclosure: the case of Indonesia. International Journal Monetary Economics and Finance, 9(4), 379-387. https://doi.org/10.1504/IJMEF.2016.080 080

Habbash, M. (2016). Corporate governance and corporate social responsibility disclosure: evidence from Saudi Arabia. Social Responsibility Journal, 12(4), 740 754. https://doi.org/10.1108/SRJ-072015-0088

Handajani, L., Subroto, B., T, S., \& Saraswati, E. (2014). Does Board Diversity Matter on Corporate Social Disclosure? Journal of Economics and Sustainable Development, $5(9), 8-16$.

Harjoto, M. A., \& Rossi, F. (2019). Religiosity, female directors, and corporate social responsibility for Italian. Journal of Business Research, 95, 338-346. https://doi.org/10.1016/j.jbusres.2018.0 8.013

Hermawan, A. (2006). Jaringan Saraf Tiruan: Teori dan Aplikasi. Yogyakarta: ANDI.

Kassem, E., Trenz, O., Hrebicek, J., \& Faldik, O. (2017). Sustainability Assessment and Reporting in Agriculture Sector. Acta Universitatis Agriculturae Mendelianae Brunensis, 65(4), 1359-1369. https://doi.org/10.11118/actaun201765 041359
Nasir, A., Ilham, E., \& Utara, V. I. (2014). Pengaruh Karakteristik Perusahaan dan Corporate Governance Terhadap Pengungkapan Sustainability Report pada Perusahaan Lq45 yang Terdaftar. Jurnal Ekonomi, 22(1).

Otoritas Jasa Keuangan. Peraturan Otoritas Jasa Kuangan No.33/POJK.04/2014 tentang Direksi dan Dewan Komisaris Emiten dan Perusahaan Publik. , Pub. L. No. 33 /POJK.04/2014 (2014).

Otoritas Jasa Keuangan. Peraturan Otoritas Jasa Keuangan No. 29 /POJK.04/2016 tentang Laporan Tahunan Emiten atau Perusahaan Publik. , Pub. L. No. 29 /POJK.04/2016 (2016).

Post, C., Rahman, N., \& Rubow, E. (2011). Green Governance: Boards of Directors' Composition and Environmental Corporate Social. Business and Society, 50(1), 189-223. https://doi.org/10.1177/0007650310394 642

Puspitaningrum, D. (2006). Pengantar Jaringan Saraf Tiruan. Yogyakarta: ANDI.

Rao, K., \& Tilt, C. (2016). Board diversity and CSR reporting: an Australian study. Meditari Accountancy Research, 24(2), 182210. https:// doi.org/10.1108/MEDAR08-2015-0052

Sarwono, J., \& Salim, H. N. (2017). Prosdurprosedur Populer Statistik untuk Analisis Data Riset Skripsi. Yogyakarta: Gava Media.

Setiawan, D., Hapsari, R. T., \& Wibawa, A. (2018). Dampak Karakteristik Dewan Direksi Terhadap Pengungkapan Corporate Social Responsibility pada Perusahaan Pertambangan di Indonesia. Jurnal Ilmiah Manajemen, VIII(1), 1-15. 
Stevenson, W. J. (2012). Operations Management. New York: McGrawHill/Irwin.

Subramanyam, K. R., \& Wild, J. J. (2010). Financial Statement Analysis (10th ed.). New York: McGraw-Hill.

Sugiyono. (2015). Metode Penelitian Pendidikan: Pendekatan Kuantitatif, Kualitatif, dan RED. Bandung: Alfabeta.

Suyanto. (2008). Soft Computing: Membangun Mesin Ber-IQ Tinggi. Bandung: Informatika Bandung.

Taghizadeh, H., \& Kermani, M. S. Z. (2011). Application of Artificial Neural Networks to Recognize the Relationship Between Corporate Social Responsibility and Financial Performance. World Applied Sciences Journal, 12(10), 19101919.

Zainal, D. (2017). Quality of Corporate Social Responsibility Reporting (CSRR): The Influence of Ownership Structure and Company Characteristics. Asian Journal of Accounting Prespective, 10, 16-35. 